\title{
Notes on the Hudnall-Pirtle Site (41RK4) in the Buddy Calvin Jones Collection at the Gregg County Historical Museum
}

Timothy K. Perttula

Heritage Research Center, Stephen F. Austin State University

Follow this and additional works at: https://scholarworks.sfasu.edu/ita

Part of the American Material Culture Commons, Archaeological Anthropology Commons, Environmental Studies Commons, Other American Studies Commons, Other Arts and Humanities Commons, Other History of Art, Architecture, and Archaeology Commons, and the United States History Commons

Tell us how this article helped you.

This Article is brought to you for free and open access by the Center for Regional Heritage Research at SFA ScholarWorks. It has been accepted for inclusion in Index of Texas Archaeology: Open Access Gray Literature from the Lone Star State by an authorized editor of SFA ScholarWorks. For more information, please contact cdsscholarworks@sfasu.edu. 
Notes on the Hudnall-Pirtle Site (41RK4) in the Buddy Calvin Jones Collection at the Gregg County Historical Museum

\section{Creative Commons License}

\section{(c) (1) \&}

This work is licensed under a Creative Commons Attribution-NonCommercial 4.0 International License 


\title{
Notes on the Hudnall-Pirtle Site (41RK4) in the Buddy Calvin Jones Collection at the Gregg County Historical Museum
}

\author{
Timothy K. Perttula
}

\section{INTRODUCTION}

The Hudnall-Pirtle site (41RK4) is an important Early Caddo (ca. A.D. 900-1200) period multiple mound center and large village situated on an alluvial terrace of the Sabine River in East Texas (Bruseth and Perttula 2006). Although best known through the archaeological investigations conducted by the Texas Historical Commission (on behalf of the Archaeological Conservancy) at the site in 1989 and 1990, Buddy Calvin Jones, then of Longview, completed his own investigations at the site in the 1950s and early 1960s (Bruseth and Perttula 2006:59; Perttula 2009), although he never published any of the archaeological findings from his work, and is has not been clear from the available records and anecdotal information (Bruseth and Perttula 2006:59; Perttula 2009:37-40) where he conducted his excavations.

At the 1963 Caddo Conference, Jones described the Hudnall-Pirtle site (which he called the Bivins Farm site) as follows:

\begin{abstract}
there is one big mound site (Bivins farm) located in the Sabine bottomlands of northeast Rusk County. It is composed of five mounds arranged around a plaza; they consist of two large rectangular temple mounds and three large circular mounds. I would guess this site to be primarily of Alto origin although tests in the village area revealed Alto and Coles Creek sherds (Davis et al. 1971:101).
\end{abstract}

Since the Hudnall-Pirtle site is now known to actually have eight mounds (Bruseth and Perttula 2006:Figure 2), it would be useful to present-day Caddo archaeologists to know which mounds Jones was referring to in his description, and how their layout and placement compared to current maps of the site. It would also be helpful if information was available on where Buddy Jones conducted excavations at Hudnall-Pirtle, and what he may have found in that work.

Until just a few months ago, all that was known or conjectured about the Buddy Calvin Jones excavations at the Hudnall-Pirtle site consisted of information gleaned in conversations with his mother, who mentioned trench excavations in Mound $\mathrm{C}$, thought to be a burial mound (Bruseth and Perttula 2006:59), and other trenches excavated in village areas and at least one mound in 1958 and 1959 (Perttula 2009:37-39). Fortunately, however, Buddy Calvin Jones maps and profiles from his work at the Hudnall-Pirtle site have been recently donated to the Gregg County Historical Museum (GCHM), although it is not known if all the notes, maps, and profiles compiled by Jones are now in the GCHM collections. This article discusses the Buddy Calvin Jones notes on his 1956-1961 work at the HudnallPirtle site.

\section{BUDDY CALVIN JONES NOTES ON THE HUDNALL-PIRTLE SITE}

Buddy Jones identified five prehistoric Caddo mounds, a sixth possible mound, a refuse area, and a borrow pit at the Hudnall-Pirtle site in a 1961 map (Figure 1); that map also showed a modern ramp house west of one of the mounds. Notably, his map does not include the southern or eastern parts of the current site area (Bruseth and Perttula 2006:Figure 2). The mound designations on this map follow those used by Bruseth and Pertula (2006:Figures 2, 4-10); on Jones' map, he used numerical designations: Mound 1 (Mound C); Mound 2 (Mound D); Mound 3 (Mound E); Mound 4 (Mound B); and Mound 5 (Mound A). The Borrow pit on Figure 1 corresponds to Borrow Pit A in Bruseth and Perttula (2006:Figure 2).

The sixth possible mound in the northwest part of the site (see Figure 1) corresponds to the 


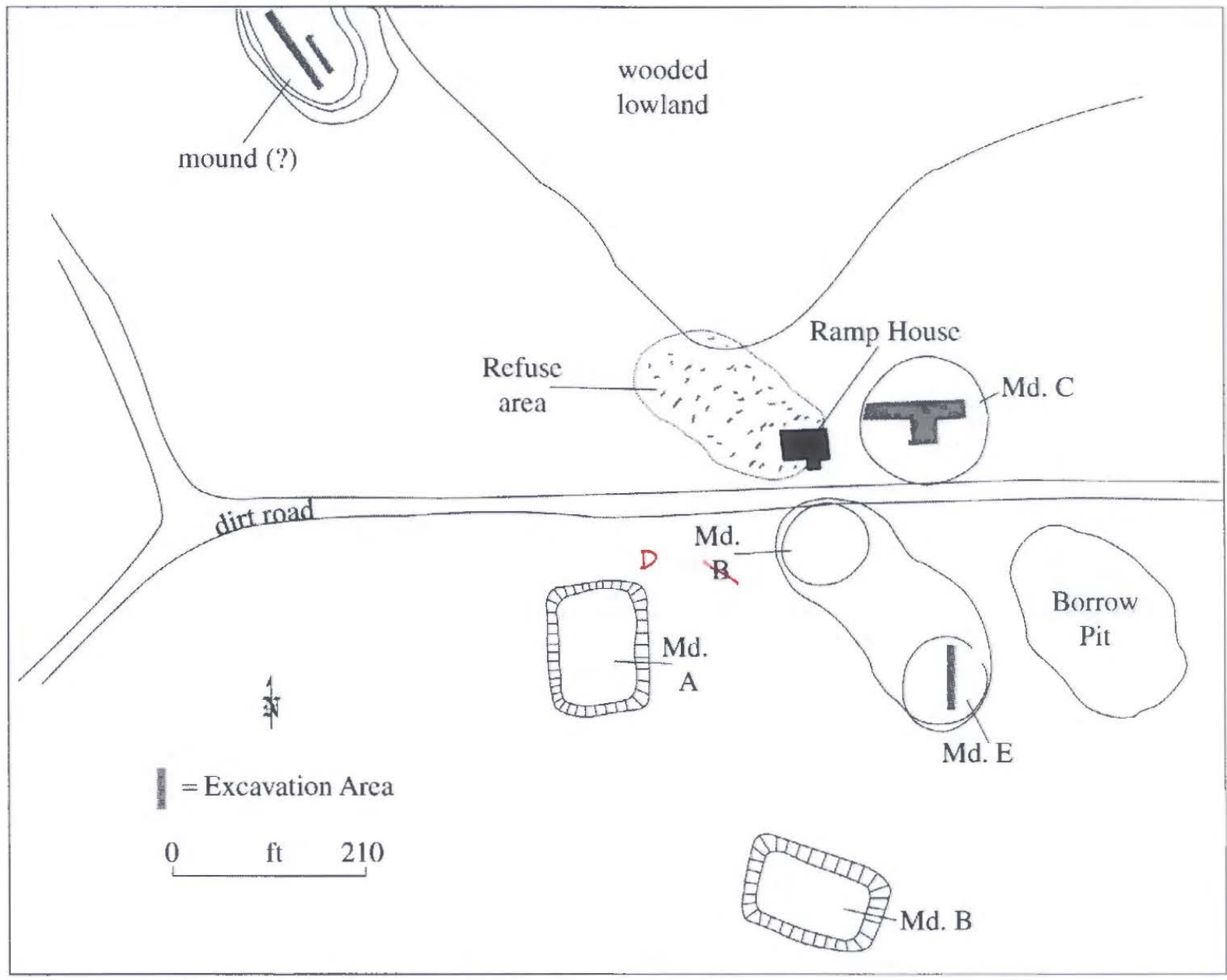

Figure 1. Buddy Jones 1961 map of the Hudnall-Pirtle site.

Northwest Area in Bruseth and Perttula (2006). Excavations here by Bruseth and Perttula (2006:68) determined that this was a natural alluvial rise, not a deliberate mound construction. Jones also identified a refuse area-presumably a product of prehistoric Caddo habitation deposits--to the immediate west of Mound C. This may be the location of his Trench $\mathrm{A}$ and B village area excavations in 1959 (Perttula 2009:37-38), which contained Early Caddo period ceramic sherds and ear spool fragments.

Mounds A and B were flat-topped platform mounds between $6-10 \mathrm{ft}$. $(1.8-3.0 \mathrm{~m})$ in height, with basal areas ranging from $16,644-27,300$ square feet (Figure 2). Mound C was conical-shaped, with a total diameter of $126 \mathrm{ft}$. and a total height of 11.75 ft. $(3.6 \mathrm{~m})$.

Jones did not excavate in either of the two flat-topped platform mounds, but did excavate a rectangular-shaped unit near the crest of Mound C in December 1956 (with the assistance of C. W.
Bailey and Jan Burandt) and an east-west trench in 1960 (see Figure 1). According to Jones' notes, the rectangular-shaped unit was excavated to a depth of $7 \mathrm{ft} .(2.1 \mathrm{~m})$, but no notable cultural features were encountered. Jones did note that clusters of pottery sherds were encountered at depths of $2 \mathrm{ft} .(0.61 \mathrm{~m})$ and $3.3 \mathrm{ft} .(1 \mathrm{~m})$ in the unit, and a piece of sandstone was found at $2.9 \mathrm{ft} .(0.88 \mathrm{~m})$. The sherds from "Cherokee Bayou Mound site, Easton" and "Easton" proveniences at the GCHM (Perttula 2009:39) may have come from these excavations.

Other excavations by Jones occurred in Mound E (see Figure 1), where in August 1961 he dug a 22 $\mathrm{ft}$. long $(6.7 \mathrm{~m})$ and $3.67 \mathrm{ft}$. wide $(1.12 \mathrm{~m})$ northsouth trench (Figure 3 ) across the center of the mound; the pothole shown in Bruseth and Perttula (2009:Figure 8) is likely the remnant of this 1961 trench. In these excavations, he documented a 4.1 $\mathrm{ft}$. high $(1.25 \mathrm{~m})$ mound with two fill stages. The mound was constructed over a Caddo house built 


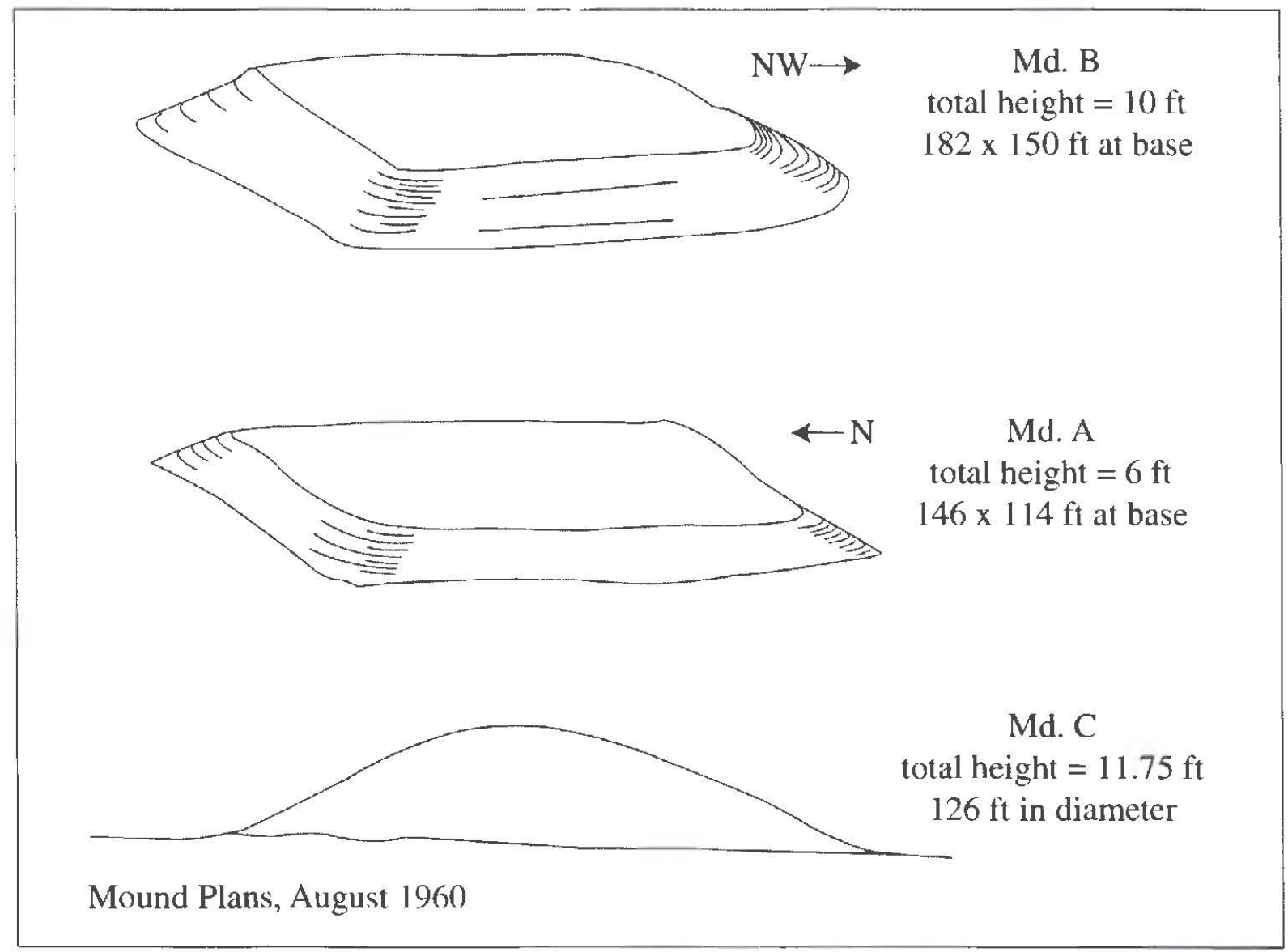

Figure 2. August 1960 drawing by Buddy Jones of Mounds A, B, and C at the Hudnall-Pirtle site.

on the natural ground surface, and the house had a 1.5 inch thick $(3.8 \mathrm{~cm})$ prepared yellow clay floor. Prepared clay floors are rare features in prehistoric and early historic Caddo structures in East Texas, whether in structures on or under mounds or on nonmound sites (Schultz 2010:328-329), suggesting the structure under the mound was likely inhabited by a member of the Caddo socio-political elitc. The house was burned-as marked by charred logs and burned clay - then buried hy the first mound fill stage, a $1.8 \mathrm{ft}$. thick $(0.56 \mathrm{~m})$ dcposit.

A second house was built upon this first mound fill stage. It was also burned, and then covered with the second mound fill stage, a $2.2 \mathrm{ft} .(0.67 \mathrm{~m})$ stcrile sand (see Figure 3 ). The second house floor was comprised of a mixture of ash and burned clay extending across much of the trench profilc. Finally, Jones suggested that there may have been a third house floor, marked by ash deposits, near the very top of the mound. If accurate, this particular burned house deposit was not capped before mound construction was terminated.
Mounds D and E as sketched by Jones (see Figure 1) suggest that they represent conjoined mounds that served as platforms for structures. Based on a comparison with the Belcher Mound sitc (16CD13) (Webb 1959), as wcll as other such mounds in the Caddo area, it is likely that throughout much of the history of the Hudnall-Pirtlc site, structures may have stood simultaneously on the two conjoined mounds. After a period of use, structures on each of the two mounds werc likely ritually burned and immediately covered by a layer of earth/mound fill.

The last excavations recorded by Jones at the Hudnall-Pirlle site were two trenches dug in 1957 in a large rise in the northwestern part of the site, which Jones thought may have also been a mound (see Figurc 1). What Jones uncovered here is unknown, although the ceramic sherds from his "North Mound, Area I" excavations (Perttula 2009:38-39) may have come from these two trenches. The sherds included Crockett Curvilinear Incised and Dunkin Incised vessels, as well as sherds from a Williams Plain vessel. 


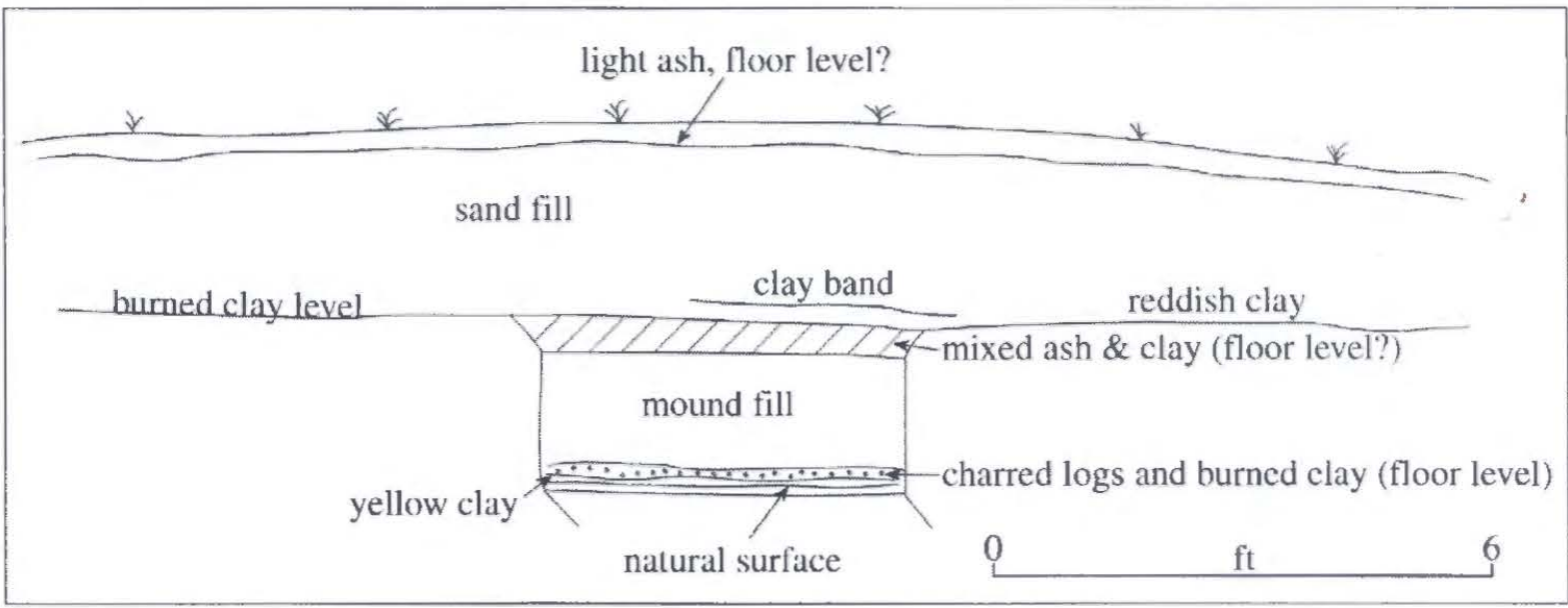

Figure 3. Profile of Mound 3 (Mound E) at the Hudnall-Pirtle site, August 1961, drawn by Buddy Calvin Jones.

\section{CONCLUSIONS}

It is fortunate that some, but hopefully not all, notes, maps, and profiles from the late 1950s-carly 1960s excavations by Buddy Calvin Jones at the Hudnall-Pirtle site have recently been donated to the Gregg County Historical Museum, where they are accessible for research studies. These notes provide specific information on the size, placement, and probable function of five of the eight mounds at this Early Caddo period site (see Figure 1); the location of a large refuse area not previously mentioned in the Hudnall-Pirtle archaeological literature; and the timing and extent of excavations by Jones in Mounds $\mathrm{C}$ and $\mathrm{E}$ as well as in a large natural rise northwest of the main mound group. The profile information from the Mound E excavations was particularly useful, in the absence of any other specific information (sec Bruseth and Perttula 2006), in that the profile clearly indicates that the mound was built over a burned house (and also suggesting a similar function for Mound D) that had a prepared clay floor. This house was apparently that of an important Caddo personage that lived there, and it was ritually abandoned and burned. Mound E served as a platform for a second ritually abandoned and burned house.

\section{ACKNOWLEDGMENTS}

I want to thank Patti Haskins, Advisory Board member at the Gregg County Historical Museum, for bringing these notes on the Hudnall-Pirtle site to my attention, and allowing me to discuss them in this article. Lance Trask prepared the figures in this article, based on copies of the original maps and profiles drawn by Buddy Jones.

\section{REFERENCES CITED}

Bruseth, J. E. and T. K. Perttula, with contributions by G. J. Fritz and B. C. Yates

2006 Archeological Investigations at the Hudnall-Pirtle Site (4IRK4): An Early Caddo Mound Center in Northeast Texas. Caddo Archeology Joumal 15:57158.

Davis, H. A., D. G. Wyckoff, and M. A. Holmes (editors)

1971 Proceedings of the Seventh Caddo Conference. Occasional Publication No. 1. Oklahoma Archeological Survey, Norman.

Perttula, T. K.

2009 Caddo Sherds from the Hudnall-Pirtle Site (41RK4) in the Buddy Jones Collection at the Gregg County Historical Museum. Journal of Northeast Texas Archaeology 3t:37-40.

Schultz, T. C.

2010 Architectural Variability in the Caddo Area of Eastern Texas. Special Publication No. 16. Friends of Northeast Texas Archaeology, Pittsburg and Austin.

Webb, C. H.

1959 The Belcher Mound: A Stratified Caddoan Site in Caddo Parish, Louisiana. Memoirs No. 16. Society for American Archaeology, Salt Lake City. 